\title{
ANALYSIS OF ACID-BASE PROPERTIES OF SOME $p$-SUBSTITUTED AROMATIC HYDRAZONES IN AQUEOUS PERCHLORIC ACID BY SPECTROPHOTOMETRIC AND SEMIEMPIRICAL METHODS
}

\author{
Mirjana S. Jankulovska ${ }^{1 *}$, Ilinka Spirevska ${ }^{2}$ \\ ${ }^{1}$ Faculty of Agricultural Sciences and Food, Ss. Cyril and Methodius University, \\ Skopje, Republic of Macedonia \\ ${ }^{2}$ Institute of Chemistry, Faculty of Natural Sciences and Mathematics, Ss. Cyril and Methodius University, \\ Skopje, Republic of Macedonia \\ jankulovska_m@yahoo.com
}

The acid-base properties of some $p$-substituted aromatic hydrazones were examined in aqueous perchloric acid medium by spectrophotometric methods. The changes in the UV spectra occurred due to the protonation reaction of the investigated hydrazones. The possible site where protonation may take place was discussed using the values of the total energy, binding energy, heat of formation and proton affinity, calculated according to the semiempirical methods AM1 and PM3. Furthermore, the stability of the protonated forms, as well as the stability of the isomers ( $E$ and $Z$ ) was discussed. Electronic absorption studies were utilized to determine the dissociation constants of the protonated form $\left(\mathrm{p} K_{\mathrm{BH}}{ }^{+}\right)$, numerically and graphically, at different ionic strengths $\left(0.1,0.25\right.$ and $\left.0.5 \mathrm{~mol} / \mathrm{dm}^{3}\right)$, as well as the thermodynamic dissociation constants. The obtained values ranged between 3.08 and 3.47. The influence of the solvent on the appearance of the spectra was compensated by the use of the method of characteristic vector analysis (CVA).

Keywords: UV spectroscopy; protonation; thermodynamic dissociation constants; $p$-substituted aromatic hydrazones; AM1 and PM3 semiempirical methods

\section{АНАЛИЗА НА КИСЕЛИНСКО-БАЗНИТЕ СВОЈСТВА НА НЕКОИ $p$-СУПСТИТУИРАНИ АРОМАТИЧНИ ХИДРАЗОНИ ВО ВОДНИ РАСТВОРИ ОД ПЕРХЛОРНА КИСЕЛИНА СО СПЕКТРОФОТОМЕТРИСКИ И СЕМИЕМПИРИСКИ МЕТОДИ}

Киселинско-базните својства на некои р-супституирани ароматични хидразони се испитани во водни раствори од перхлорна киселина со спектрофотометриски методи. Како резултат на реакцијата на протонирање се забележани промени во UV-спектрите. Местото каде протонирањето може да се одвива е дискутирано со користење на вредностите на вкупната енергија, сврзувачката енергија, топлината на формирање и протонскиот афинитет, пресметани со примена на семиемпириските методи AM1 и РМ3. Исто така е дискутирана стабилноста на протонираните форми, како и стабилноста на изомерите $(E$ и $Z)$. Електронските апсорпциони спектри се искористени за определување на константите на дисоцијација на протонираната форма $\left(\mathrm{p} K_{\mathrm{BH}}{ }^{+}\right)$, нумерички и графички, при различна јонска сила $\left(0,1,0,25\right.$ и $\left.0,5 \mathrm{~mol} / \mathrm{dm}^{3}\right)$, како и термодинамичките константи на дисоцијација.

Добиените вредности се движат во границите од 3,08 до 3,47. Влијанието на растворувачот на изгледот на спектрите е компензирано со примена на методот на карактеристична векторска анализа (CVA).

Клучни зборови: UV-спектроскопија; протонирање; термодинамички константи на дисоцијација; p-супституирани ароматични хидразони; семиемпириските методи AM1 и PM3 


\section{INTRODUCTION}

Hydrazones are considered one of the most important classes of organic compounds. Their derivatives constitute an important class of organic compounds showing diverse biological activity such as: anticonvulsant, antidepressant, analgesic, antiinflammatory, antiplatelet, antimicrobial, antimalarial, antitumoral, antiviral, vasodilator and antitubeculosis [1-6]. This activity of hydrazones and their derivatives is a result of having an azometine proton $(-\mathrm{NH}-\mathrm{N}=\mathrm{CH}-)$. As a result of the presence of this proton, hydrazones find wide applications in many areas. They can also be used in agriculture as herbicides, insecticides and plant growth stimulants [7]. Furthermore, they are used in synthetic organic chemistry for the preparation of other compounds, and in analytical chemistry for the identification of carbonyl compounds $[8,9]$. The hydrazones also find applications as spectrophotometric reagents, because they can act as multidentate ligands with transition metals [10].

Acidity measurements of organic compounds, like those investigated here, are significant in studies that involve the formation and investigation of biological activities. An understanding of the acidity or basicity of organic compounds is fundamental to molecular design. The reaction mechanisms are also very important for understanding the chemical and biological processes that may take place at the azometine site [11]. It is wellknown that acid-base properties affect the toxicity and pharmaceutical characteristics of organic acids and bases [12]; the biological activity of hydrazones depends on the ionic forms in which they exist in solution [13].

Moreover, knowledge of the ionization constant values of ionizable groups is important for understanding of many areas of chemistry. It should be pointed out that the values of these constants are important, especially for elucidating the reaction mechanism, especially those involving proton transfers. There are several different methods, such as potentiometric, chromatographic, electrophoretic and spectrophotometric methods, that can be used for the determination of the ionization constants of compounds that behave as weak bases in acidic media. It is known that spectrophotometric methods are highly sensitive and suitable for studying chemical equilibria in solution [14].

The proton-acceptor and proton-donor capacities of drug molecules are significant factors in the functioning of biological systems. With knowledge of the ionization constants, one can calculate the ratio of the molecules with different protonation sites at various $\mathrm{pH}$ values in certain compartments of the body. It is also important to know the average protonation state of the molecule when designing in vitro chemical reactions and analytical procedures [15]. So far, no precise data have been available in the literature referring to the sites where the molecule loses and accepts protons. However, the recent development of a calculation method in quantum chemistry has facilitated a new approach to the analysis of acid-base properties of biologically active compounds [16].

In view of the above observations, this work focused on following the behavior of some $p$-substituted aromatic hydrazones in acidic media $(\mathrm{pH}$ range from 1 to 7), as well as on the determination of the ionization constants of their protonated forms $\left(\mathrm{p}{\mathrm{BH}^{+}}^{+}\right)$. Moreover, the thermodynamic ionization constants were evaluated from the $\mathrm{p} K_{\mathrm{BH}}{ }^{+}$values determined at different ionic strengths. Additionally, applying the semiempirical methods AM1 and PM3, the proton affinities, site of protonation and stability of the protonated forms and that of the isomers $(E$ and $Z)$ were determined.

The $p$-substituted aromatic hydrazones that were the subject of this study have the general structural formula shown in Table 1.

Table 1

The structure and nomenclature of the investigated hydrazones

\begin{tabular}{ccc}
\hline \hline & \\
& & \\
\hline Compound & $N$-benzaldehyde- $p$-metoxybenzoilhydrazone & Substituents \\
\hline $\mathrm{H}_{1}$ & $N$ - $p$-methylbenzaldehyde- $p$-metoxybenzoilhydrazone & $-\mathrm{H}$ \\
$\mathrm{H}_{2}$ & $N$ - -metoxybenzaldehyde- $p$-metoxybenzoilhydrazone & $-\mathrm{CH}_{3}$ \\
$\mathrm{H}_{3}$ & $-\mathrm{OCH}_{3}$ \\
$\mathrm{H}_{4}$ & $N$-chlorobenzaldehyde- $p$-metoxybenzoilhydrazone & $-\mathrm{Cl}$ \\
$\mathrm{H}_{5}$ & $N$-hydroxybenzaldehyde- $p$-metoxybenzoilhydrazone & $-\mathrm{OH}$ \\
\hline \hline
\end{tabular}


These hydrazones were synthesized in our laboratory and their structures were confirmed by several methods, including UV, IR, ${ }^{1} \mathrm{H}$ NMR, ${ }^{13} \mathrm{C}$ NMR and elemental analysis [17].

\section{EXPERIMENTAL}

\subsection{Solutions and measurements}

Stock solutions were prepared by dissolving an accurate weight of the compound in the appropriate volume of $98 \%$ ethanol. The concentration of the investigated hydrazones in these solutions was about $1 \cdot 10^{-3} \mathrm{~mol} / \mathrm{dm}^{3}$. The stock solutions were stable over a long period of time, under ordinary conditions. The test solutions of individual hydrazones were prepared with redistilled water; the concentration of hydrazone was approximately $3 \cdot 10^{-5} \mathrm{~mol} / \mathrm{dm}^{3}$. In order to obtain more precise data, a three series of test solutions were prepared, and $\mathrm{p} K_{\mathrm{BH}}{ }^{+}$values were calculated as the average value of these data.

In all test solutions, sodium perchlorate (1 $\mathrm{mol} / \mathrm{dm}^{3}$ ) was added to adjust the ionic strength $\left(0.1,0.25\right.$ and $\left.0.5 \mathrm{~mol} / \mathrm{dm}^{3}\right)$, while the $\mathrm{pH}$ was varied in the range between 1 and 7 by adding a suitable amount of perchloric acid $\left(0.5 \mathrm{~mol} / \mathrm{dm}^{3}\right)$. After each $\mathrm{pH}$ adjustment, the UV spectra were recorded. Simultaneously, the blanks were prepared with the same composition as the working solutions, without the investigated hydrazone.

The purity of the investigated hydrazones was confirmed by elemental analysis, as well as constant measurement of melting points. The perchloric acid and sodium perchlorate were of analytical grade p.a.

Absorbance measurements were carried out using a quartz cell with a $1 \mathrm{~cm}$ path length in a Varian Cary $50 \mathrm{UV} / \mathrm{V}$ is spectrophotometer (the maximum scan rate is $24000 \mathrm{~nm} / \mathrm{min}$ and resolution is $1.5 \mathrm{~nm}$ ), immediately after preparation of the solutions, at room temperature.

All absorption spectra were digitized at five data points per nanometer in the wavelength region between 190 and $400 \mathrm{~nm}$. The $\mathrm{pH}$ measurements were carried out using a digital $\mathrm{pH}$ meter with a combined glass electrode $(1<\mathrm{pH}<13)$, calibrated with two buffer solutions at $\mathrm{pH} 4$ and $\mathrm{pH} 7$.

\subsection{Calculations}

$\mathrm{p} K_{\mathrm{BH}}{ }^{+}$values can be calculated from the absorbance value which corresponds to the absorption maximum; more than one absorbance value can be used. Our previous studies demonstrated that the obtained results are more accurate when four absorbance values are used [18]. Furthermore, the $\mathrm{p}{\mathrm{BH}_{\mathrm{BH}}}^{+}$values calculated from the absorbance values at four selected wavelengths around the absorption maximum in neutral media are statistically identical with those in acid media. It has been suggested that both maxima can be used for the selection of wavelengths for further calculations [18]. Taking into consideration these results, the calculations of the $\mathrm{p} K_{\mathrm{BH}}{ }^{+}$values were performed from the absorbance values from experimental and reconstructed spectra at four selected wavelengths around the absorption maximum that appears in neutral media: $306 \mathrm{~nm}, 310 \mathrm{~nm}, 314 \mathrm{~nm}$ and 318 $\mathrm{nm}$. To determine the molar absorption coefficients, the absorbance values of the neutral $(\mathrm{pH}$ 6.7) and protonated ( $\mathrm{pH} \mathrm{2.1)} \mathrm{form} \mathrm{were} \mathrm{measured.}$ For this purpose, the UV spectra were recorded at three different concentrations $\left(2.40 \cdot 10^{-5}, 3.00 \cdot 10^{-5}\right.$ and $3.60 \cdot 10^{-5} \mathrm{~mol} / \mathrm{dm}^{3}$ ) of the investigated hydrazones in solution at ionic strengths $0.1 \mathrm{~mol} / \mathrm{dm}^{3}$, $0.25 \mathrm{~mol} / \mathrm{dm}^{3}$ and $0.5 \mathrm{~mol} / \mathrm{dm}^{3}$. Furthermore, the ionization ratio $I\left(I=c\left(\mathrm{BH}^{+}\right) / c(\mathrm{~B})\right)$, i.e. the ratio between the concentration of the protonated $\left(\mathrm{BH}^{+}\right)$ and neutral (B) form of the hydrazones, was determined. The calculations were performed using the molar absorption coefficient values and the spectrophotometric data obtained at the selected wavelengths, in accordance with Beer's law. In order to minimize the influence of random errors, an overdetermined system of four equations (for absorbance values) with two unknown parameters (concentration of the protonated and unprotonated form) was set up. The $\mathrm{pK}_{\mathrm{BH}}{ }^{+}$values were calculated using the Equation (1) presented below:

$$
\mathrm{p}{K_{\mathrm{BH}}}^{+}=n \cdot \mathrm{pH}+\log I,
$$

where $\mathrm{pK}_{\mathrm{BH}}{ }^{+}$is the dissociation constant of the protonated form, $I$ is the ionization ratio and $n$ is the number of protons.

The influence of the solvent can be eliminated by employing various methods such as principal component analysis (PCA) [19], the target-testing method of factor analysis [20] and characteristic vector analysis (CVA) [21]. One of the most commonly used is CVA, which has been tested and proven to be applicable in the analysis of spectroscopic data, to investigate problems dealing with protonation [22].

Additionally, the $\mathrm{p} K_{\mathrm{BH}}{ }^{+}$values of the investigated hydrazones were determined graphically [23], as the intercept of the dependence of $\log I$ on $\mathrm{pH}$. When $c\left(\mathrm{BH}^{+}\right)=c(\mathrm{~B}), \log I=0$, the graphically 
determined $\mathrm{p} \mathrm{BH}_{\mathrm{BH}}^{+}$value is equal to the $\mathrm{pH}$ value of the solution. Finally, with extrapolation of the curve $\mathrm{p} K_{\mathrm{BH}}{ }^{+}=f(\sqrt{\mu})$ to zero ionic strength, the thermodynamic $\mathrm{p}{K_{\mathrm{BH}}}^{+}$values were evaluated, as the intercept [24].

The semiempirical calculations (heat of formation, proton affinities, total energy, binding energy and Gibbs energies of formation) were performed using semiempirical the AM1 (Austin Model 1) and PM3 (Parametric Method 3) methods $[25,26]$. Preliminary optimization was performed by the molecular mechanics $\mathrm{MM}^{+}$with application of the Polak-Ribiere algorithm and a gradient of $0.1 \mathrm{kcal} /(\mathrm{A} \cdot \mathrm{mol})$. The same methods were applied to optimize the geometry of the analyzed hydrazones and to determine the stability of the possible isomers.

All the results were obtained using the computer programs Excel, Grams Version 4.10, and HyperChem Version 8.

\section{RESULTS AND DISCUSSION}

\subsection{The absorption spectra and characterization of electron transitions}

The UV spectra of $N$-benzaldehyde- $p$-metoxybenzoilhydrazone $\left(\mathbf{H}_{\mathbf{1}}\right), \quad N$-p-methylbenzaldehyde- $p$-metoxybenzoilhydrazone $\left(\mathbf{H}_{2}\right), N$ - $p$-metoxybenzaldehyde- $p$-metoxybenzoilhydrazone $\left(\mathbf{H}_{\mathbf{3}}\right)$, $N$ - $p$-chlorobenzaldehyde- $p$-metoxybenzoilhydrazone $\left(\mathbf{H}_{4}\right)$ and $N$-p-hydroxybenzaldehyde- $p$-metoxybenzoilhydrazone $\left(\mathbf{H}_{5}\right)$ were obtained in aqueous perchloric acid medium (pH from 2 to 6 ) at room temperature. These spectra were recorded in the wavelength region from 190 to $400 \mathrm{~nm}$, as shown for hydrazone $\mathbf{H}_{3}$ (Figure 1). Predictably, similar spectra were obtained for the other investigated hydrazones.

As can be seen from the UV spectra (see Figure 1), it is clear that in the investigated wavelength region, two absorption bands exist in the spectra of the hydrazone $\mathbf{H}_{3}$, in the $\mathrm{pH}$ range from 2 to 6 . The first absorption band that appears in the neutral region, at a wavelength around $195 \mathrm{~nm}(\varepsilon=$ $307632 \mathrm{~cm}^{-1} \mathrm{~mol}^{-1} \mathrm{dm}^{3}$ ), is a result of $\pi \rightarrow \pi^{*}$ electron transitions. Moreover, the second absorption band, found at around $314 \mathrm{~nm}\left(\varepsilon=344548 \mathrm{~cm}^{-1}\right.$ $\mathrm{mol}^{-1} \mathrm{dm}^{3}$ ), is due to low energy $n \rightarrow \pi^{*}$ electron transition of the azometine group, involving the lone pair on the azometine nitrogen atom, and characterizes the neutral form of the compound. This absorption band was interesting for our further investigations.

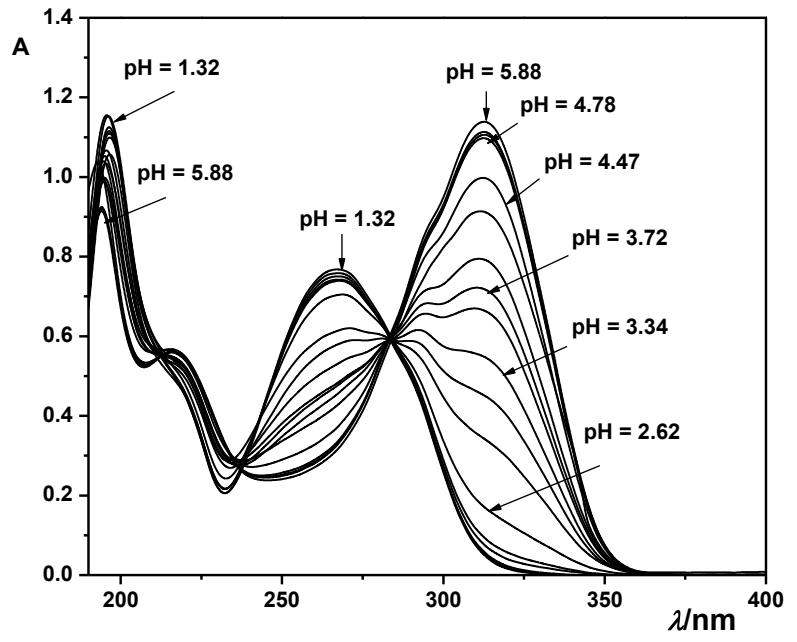

Fig. 1. The experimental UV spectra for $N-p$-metoxybenzaldehyde- $p$-metoxybenzoilhydrazone $\left(c=3.21 \cdot 10^{-5}\right.$ $\mathrm{mol} / \mathrm{dm}^{3}$ ) in perchloric acid media ( $\mathrm{pH}$ from 1.3 to 5.8 ) at an ionic strength of $0.1 \mathrm{~mol} / \mathrm{dm}^{3}\left(\mathrm{NaClO}_{4}\right)$

Upon increasing the acidity of the solution until $\mathrm{pH} 4.78$, there were no changes in the position and intensity of this absorption band. On the other hand, when the $\mathrm{pH}$ was lower than 4.47 , the intensity of the absorption band decreased (Figure 1 ), while when the $\mathrm{pH}$ of the solution was below 3.53 , despite no change in intensity except intensity, a hypsochromic shift of the absorption band of about $20 \mathrm{~nm}$ was observed. In more acidic media ( $\mathrm{pH} 2.44)$, the absorption band reached the final position $(266 \mathrm{~nm})$ and there were no further changes in its intensity. However, as can be seen in Figure 1, acidification of the investigated solutions resulted in an approximate $50 \mathrm{~nm}$ hypsochromic shift in the absorption band.

The described changes in the experimental spectra suggested that the reaction of protonation of the investigated hydrazones probably occurred in acidic media. Namely, it is known that this absorption band which is a result of $n \rightarrow \pi^{*}$ transitions despaired in acidic media when the protonation process of compounds that contain an azometine group take place, i.e. transitions where a proton is added to the azometine group are hindered. The absorption band which appears in acidic media $(\mathrm{pH}$ 2.4) at lower wavelengths (around $266 \mathrm{~nm}$ ) is probably a result of the $\pi \rightarrow \pi^{*}$ electron transitions of the protonated form of hydrazones. Furthermore, changes were noted in the intensity and the position of the first absorption band. However, as mentioned before, this absorption band was not interesting for our further investigations.

In addition, in Figure 1 it can clearly be seen that isosbestic points can be expected in the expe- 
rimental spectra of the hydrazone $\mathbf{H}_{3}$. In order to determine their exact positions, the experimental spectra were reconstructed using the CVA method. The obtained spectra after reconstruction are shown in Figure 2.

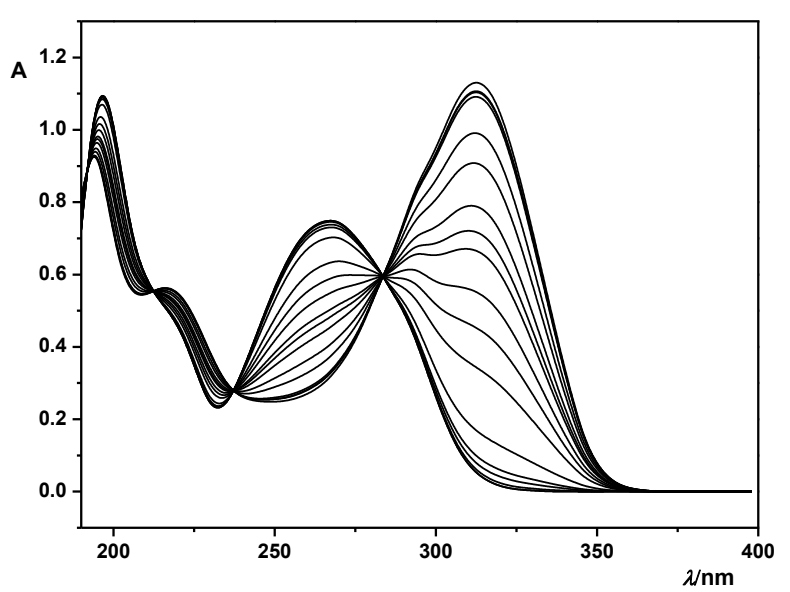

Fig. 2. The reconstructed UV spectra for $N$-p-metoxybenzaldehyde- $p$-metoxybenzoilhydrazone $\left(c=3.21 \cdot 10^{-5} \mathrm{~mol} / \mathrm{dm}^{3}\right)$ at an ionic strength of $0.1 \mathrm{~mol} / \mathrm{dm}^{3}\left(\mathrm{NaClO}_{4}\right)$

From the reconstructed spectra (see Figure 2), it can be seen that for the hydrazone $\mathbf{H}_{3}$, the isosbestic points around 214, 238 and $286 \mathrm{~nm}$ are clearly visible. The position and the intensity of the absorption bands do not change after reconstructtion. The existence of the isosbestic points indicates that a reaction is taking place in the studied solutions and there are at least two molecular species present capable of absorbing electromagnetic radiation.

Based on the changes in the UV spectra for all investigated hydrazones, we concluded that the reaction that occurs in acidic media is the protonation of hydrazones. This conclusion was additionally supported by the variation of the absorbance at $314 \mathrm{~nm}$ after changing the acidity of the solution. These curves $(A=f(\mathrm{pH}))$ for all investigated hydrazones have a sigmoidal „S" shape (see Figure 3).

The curves shown in Figure 3 have only one step, which is an indication that only one reaction takes place. Its initial part is almost horizontal until a $\mathrm{pH}$ of about 5.0. After that, the curves rise until a $\mathrm{pH}$ of 2.5 and then the absorbance values remain practically constant. The changes in the sigmoidal curve of the hydrazone $\mathbf{H}_{3}$ (see Figure 3 ) showed that formation of the protonated form of this hydrazone occurred when the $\mathrm{pH}$ of the solution was below 2.5. The identical situation for the other investigated hydrazones was observed. Using the
„S"-shaped curve, the $\mathrm{pH}$ range of protonation of each investigated hydrazone (steep part), and the $\mathrm{pH}$ values at which only the neutral or the protonated form (horizontal part) exist, can be determined (see Figure 3).

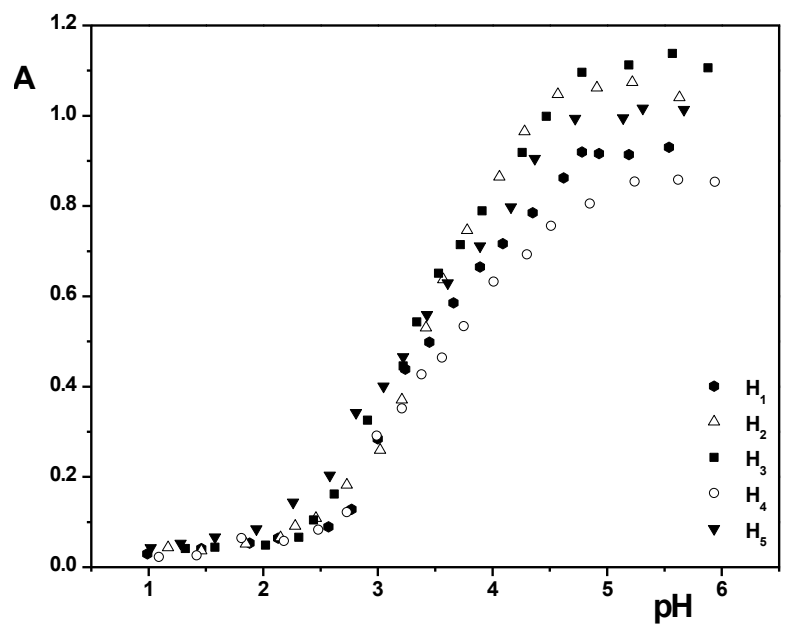

Fig. 3. The absorbance values at $\lambda=314 \mathrm{~nm}$, for hydrazones $\mathbf{H}_{1}-\mathbf{H}_{5}$ as a function of $\mathrm{pH}$ in aqueous perchloric acid media

For the protonation equilibrium of a base, the following equation can be written:

$$
\mathrm{B}+\mathrm{H}_{3} \mathrm{O}^{+}=\mathrm{BH}^{+}+\mathrm{H}_{2} \mathrm{O}
$$

In order to make it applicable to a given reaction only, the exact position of the site at which protonation takes place must be determined. To achieve that, the proton affinities of possible protonation sites and some physicochemical parameters (total energy, binding energy and heat of formation) we calculated, using the semiempirical methods AM1 and PM3.

\subsection{Physicochemical parameters and proton affinities}

Possible sites of protonation of a hydrazone molecule are the azometine nitrogen atoms i.e. the $\mathrm{sp}^{2}$ (imino) and $\mathrm{sp}^{3}$ (amino) hybridized nitrogen atoms, which can exist in acidic solution as cations. The electronic properties of the investigated hydrazones and their stabilities were determined with full geometry optimization by the AM1 and PM3 semiempirical methods. The obtained results for total energy $\left(E_{\mathrm{tot}}\right)$, binding energy $\left(E_{\text {bind }}\right)$ and heat of formation $\left(\Delta H_{\mathrm{f}}^{\mathrm{o}}\right)$ are given in Tables 2 (AM1) and 3 (PM3). 
Table 2

Physicochemical parameters of nitrogen cations $\left(N-s p^{2}\right.$ and $N$-sp $\left.p^{3}\right)$ calculated with the AM1 method

\begin{tabular}{clcccc}
\hline \hline & Form & ${ }^{*} E_{\text {tot }}$ & $E_{\text {bind }}$ & $\Delta H_{f}^{\circ}$ & Charge \\
\hline \multirow{2}{*}{$\mathbf{H}_{\mathbf{1}}$} & $\mathrm{N}-s p^{2}$ & -73165.90 & -3517.13 & 172.86 & -0.043 \\
& $\mathrm{~N}-s p^{3}$ & -73155.40 & -3506.66 & 183.33 & -0.306 \\
\multirow{2}{*}{$\mathbf{H}_{2}$} & $\mathrm{~N}-s p^{2}$ & -76760.94 & -3800.45 & 164.45 & -0.043 \\
& $\mathrm{~N}-s p^{3}$ & -76752.70 & -3792.25 & 172.83 & -0.306 \\
\multirow{3}{*}{$\mathbf{H}_{3}$} & $\mathrm{~N}-s p^{2}$ & -84141.20 & -3891.12 & 133.52 & -0.045 \\
& $\mathrm{~N}-s p^{3}$ & -84133.80 & -3883.71 & 140.94 & -0.306 \\
$\mathbf{H}_{4}$ & $\mathrm{~N}-s p^{2}$ & -81468.50 & -3499.27 & 167.61 & -0.047 \\
& $\mathrm{~N}-s p^{3}$ & -81458.10 & -3488.86 & 178.02 & -0.305 \\
$\mathbf{H}_{5}$ & $\mathrm{~N}-s p^{2}$ & -80559.80 & -3621.52 & 128.04 & -0.045 \\
& $\mathrm{~N}-s p^{3}$ & -80550.00 & -3611.65 & 137.90 & -0.306 \\
\hline \hline
\end{tabular}

*All energy parameter values are in $\mathrm{kcal} / \mathrm{mol}$

T a b l e 3

Physicochemical parameters of nitrogen cations calculated with the PM3 method

\begin{tabular}{cccccc}
\hline \hline & Form & ${ }^{*} E_{\text {tot }}$ & $E_{\text {bind }}$ & $\Delta H^{\circ}$ & Charge \\
\hline \multirow{2}{*}{$\mathbf{H}_{\mathbf{1}}$} & $\mathrm{N}-s p^{2}$ & -67133.70 & -3520.92 & 169.07 & -0.116 \\
& $\mathrm{~N}-s p^{3}$ & -67126.40 & -3513.64 & 176.35 & -0.009 \\
$\mathbf{H}_{\mathbf{2}}$ & $\mathrm{N}-s p^{2}$ & -70586.80 & -3806.01 & 159.07 & -0.117 \\
& $\mathrm{~N}-s p^{3}$ & -70580.50 & -3799.65 & 165.44 & -0.008 \\
$\mathbf{H}_{3}$ & $\mathrm{~N}-s p^{2}$ & -77348.10 & -3894.74 & 129.90 & -0.116 \\
& $\mathrm{~N}-s p^{3}$ & -77342.00 & -3888.72 & 135.93 & -0.011 \\
$\mathbf{H}_{\mathbf{4}}$ & $\mathrm{N}-s p^{2}$ & -74083.30 & -3503.30 & 163.58 & -0.120 \\
& $\mathrm{~N}-s p^{3}$ & -74076.50 & -3496.52 & 170.36 & -0.008 \\
$\mathbf{H}_{5}$ & $\mathrm{~N}-s p^{2}$ & -73911.60 & -3626.33 & 123.22 & -0.116 \\
\hline \hline
\end{tabular}

*All energy parameter values are in $\mathrm{kcal} / \mathrm{mol}$

It was assumed that the most probable structure is the one for which the calculated values are the lowest. From the results obtained using the semiempirical AM1 method, it was seen that the $s p^{2}$ hybridized nitrogen cation had lower energies $\left(E_{\mathrm{tot}}\right.$, $E_{\text {bind }}$ and $\Delta H_{\mathrm{f}}^{\mathrm{o}}$ ) than the $\mathrm{sp}^{3}$ hybridized one (see Table 2). These results were confirmed with the semiempirical method PM3 (see Table 3).

On the other hand, the lowest energies for both the $\mathrm{N}-\mathrm{sp}^{2}$ and $\mathrm{N}-\mathrm{sp}^{3}$ protonated forms were $\mathrm{ob}-$ tained for hydrazone $\mathbf{H}_{3}$, while the highest energies were observed for hydrazone $\mathbf{H}_{\mathbf{1}}$. This suggests that the protonated form of hydrazone $\mathbf{H}_{3}$ was more stable in solution than those of the other hydrazones. It must be pointed out that all values of the analyzed energies for the investigated hydrazones were close (Tables 2 and 3). However, according to these calculations, we could conclude that the protonation of the imino hybridized nitrogen atom $\left(\mathrm{sp}^{2}\right)$ was most probable.
Furthermore, the conclusion regarding the protonation site can be tested by comparison of the partial charges calculated with the semiempirical methods. These values evaluated with the AM1 semiempirical method (Table 2) indicate protonation of the $\mathrm{sp}^{3}$ hybridized nitrogen atom, while those evaluated using PM3 (Table 3) suggest the opposite situation, i.e. protonation of the $\mathrm{sp}^{2}$ hybridized nitrogen atom. To resolve this situation, the proton affinity values of both nitrogen atoms $\left(\mathrm{sp}^{2}\right.$ and $\mathrm{sp}^{3}$ hybridized) should be calculated. The calculations were performed using the heat of formation $\left(\Delta H_{\mathrm{f}}\right)$ and Gibbs energy of formation $\left(\Delta G_{\mathrm{f}}\right)$, according to the Equations (3) and (4):

$$
\begin{gathered}
\mathrm{PA}=\Delta G_{\mathrm{f}}(\mathrm{B})+\Delta G_{\mathrm{f}}\left(\mathrm{H}^{+}\right)-\Delta G_{\mathrm{f}}\left(\mathrm{BH}^{+}\right) \\
\mathrm{PA}=\Delta H_{\mathrm{f}}^{o}(\mathrm{~B})+\Delta H_{\mathrm{f}}^{o}\left(\mathrm{H}^{+}\right)-\Delta H_{\mathrm{f}}^{o}\left(\mathrm{BH}^{+}\right)
\end{gathered}
$$

where PA is the proton affinity, $\Delta H_{\mathrm{f}}^{\mathrm{o}}(\mathrm{B}) / \Delta G_{\mathrm{f}}(\mathrm{B})$ is the heat/Gibbs energy of formation for the mole- 
cule, $\Delta H_{\mathrm{f}}\left(\mathrm{BH}^{+}\right) / \Delta G_{\mathrm{f}}\left(\mathrm{BH}^{+}\right)$is the heat/Gibbs energy of formation for the cation and $\Delta H_{\mathrm{f}}^{\mathrm{o}}\left(\mathrm{H}^{+}\right) / \Delta G_{\mathrm{f}}\left(\mathrm{H}^{+}\right)$ is the heat/Gibbs energy for the proton formation and has the value of $367.2 / 362.57 \mathrm{kcal} / \mathrm{mol}[27,28]$.
The results from both semiempirical methods (AM1 and PM3), provided using Equation (3), are presented in Table 4.

T a b le 4

$$
\begin{gathered}
\Delta H_{f}^{\mathrm{o}} \text { of neutral }(B) \text { and protonated }\left(B H^{+}\right) \text {forms }\left(\mathrm{sp}^{2} \text { and } s p^{3}\right. \text { hybridized nitrogen atoms) } \\
\text { and } P A \text { of hydrazones } \boldsymbol{H}_{1}-\boldsymbol{H}_{5}
\end{gathered}
$$

\begin{tabular}{|c|c|c|c|c|c|c|c|c|c|}
\hline & & \multicolumn{2}{|c|}{ Neutral form } & \multicolumn{3}{|c|}{$s p^{2}$ protonated form } & \multicolumn{3}{|c|}{$s p^{3}$ protonated form } \\
\hline \multicolumn{2}{|c|}{ Compound } & ${ }^{*} \Delta G_{f}(\mathrm{~B})$ & $\Delta S(\mathrm{~B})$ & $\Delta G_{f}\left(\mathrm{BH}^{+}\right)$ & $\Delta S\left(\mathrm{BH}^{+}\right)$ & $\mathrm{PA}\left(G_{f}\right)$ & $\Delta G_{f}\left(\mathrm{BH}^{+}\right)$ & $\Delta S\left(\mathrm{BH}^{+}\right)$ & $\mathrm{PA}\left(G_{f}\right)$ \\
\hline \multirow{5}{*}{$\bar{\sum}$} & $\mathbf{H}_{1}$ & -16.26 & 0.1258 & 131.65 & 0.1383 & 214.65 & 143.36 & 0.1341 & 202.94 \\
\hline & $\mathrm{H}_{2}$ & -25.64 & 0.1308 & 120.25 & 0.1489 & 216.67 & 127.80 & 0.1511 & 209.12 \\
\hline & $\mathbf{H}_{3}$ & 59.06 & 0.1396 & 88.46 & 0.1512 & 333.16 & 96.21 & 0.1501 & 325.41 \\
\hline & $\mathrm{H}_{4}$ & -25.24 & 0.1326 & 124.45 & 0.1448 & 212.87 & 136.68 & 0.1387 & 200.64 \\
\hline & $\mathbf{H}_{5}$ & 62.82 & 0.1312 & 84.83 & 0.1450 & 340.55 & 96.98 & 0.1373 & 328.40 \\
\hline \multirow{5}{*}{$\sum_{0}^{\infty}$} & $\mathrm{H}_{1}$ & -25.45 & 0.1381 & 210.24 & 0.1417 & 210.24 & 135.19 & 0.1381 & 201.89 \\
\hline & $\mathbf{H}_{2}$ & -34.94 & 0.1381 & 113.45 & 0.1531 & 214.17 & 122.02 & 0.1457 & 205.60 \\
\hline & $\mathbf{H}_{3}$ & 68.05 & 0.1513 & 83.56 & 0.1555 & 347.05 & 90.22 & 0.1534 & 340.39 \\
\hline & $\mathbf{H}_{4}$ & -33.93 & 0.1441 & 119.32 & 0.1485 & 209.31 & 126.70 & 0.1465 & 201.93 \\
\hline & $\mathrm{H}_{5}$ & 72.58 & 0.1427 & 79.33 & 0.1473 & 355.81 & 88.58 & 0.1414 & 346.56 \\
\hline
\end{tabular}

${ }^{*} \Delta G=\Delta H-T \Delta S, \Delta G_{f} ; \mathrm{PA}-\mathrm{kcal} / \mathrm{mol} ; \Delta S-\mathrm{kcal} / \mathrm{mol} \cdot \mathrm{K}$

The obtained results (see Table 4) show that the $\mathrm{sp}^{2}$ hybridized nitrogen atom has higher proton affinity values compared to those of the $\mathrm{sp}^{3}$ hybridized one. This indicates that the protonation reaction takes place at the nitrogen atom which is $s p^{2}$ hybridized, i.e. the imino nitrogen atom. This conclusion is in accordance with the results of the protonation site of hydrazones known from the literature $[16,29,30]$. Furthermore, the hydrazones $\mathbf{H}_{5}$ and $\mathbf{H}_{3}$ have greater proton affinity compared to the other investigated hydrazones, which have similar values for proton affinity. The lowest proton affinity was $212.87 / 209.32 \mathrm{kcal} / \mathrm{mol}$ (AM1/PM3) for hydrazone $\mathbf{H}_{4}$. According to the calculated values of proton affinities and data known from the literature, the chemical reaction describing the protonation of hydrazones in acidic media can be presented as follows:

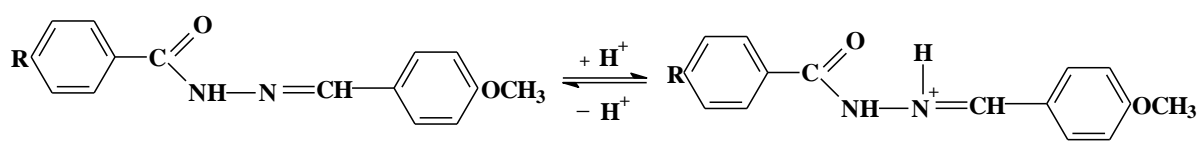

The similarity of the PA values of both nitrogen atoms suggests that the influence of the substituents present in the investigated hydrazone molecules on the protonation site is not significant.

Furthermore, we did some investigations related to the stability of the syn $(Z)$ and anti $(E)$ stereo isomers of the neutral and protonated forms of hydrazone molecules. As is well-known, the syn $(Z)$ and anti $(E)$ stereo isomers are possible for the amide hydrazone structures of the investigated compounds. Applying the above mentioned semiempirical methods, the geometries of the $E$ and $Z$ isomers were optimized. The stability of the isomers and their $\mathrm{sp}^{2}$ protonated forms was deter- mined using the values of $E_{\text {tot }}$ (in $\mathrm{kcal} / \mathrm{mol}$ ) and $\Delta H_{\mathrm{f}}^{\mathrm{o}}$ (in $\mathrm{kcal} / \mathrm{mol}$ ). The PA values (in $\mathrm{kcal} / \mathrm{mol}$ ) for both isomers were calculated using the heat of formation values, according to Equation (4). The obtained results for the neutral and $\mathrm{sp}^{2}$ protonated forms are given in Tables 5 (AM1) and 6 (PM3).

The obtained results indicate that the $E$ isomer is more stable (it has a lower value of $E_{\text {tot }}$; see Tables 5 and 6) than the $Z$ isomer in neutral media, for all the investigated hydrazones. The situation is different in acidic media, when the cation is formed as a result of protonation of the $\mathrm{sp}^{2}$ hybridized nitrogen atom. In this case, the stability of the $Z$ isomer is greater compared to the $E$ isomer. 
This can be explained by the PA values of both isomers. As seen in Tables 5 and 6, the $Z$ isomers of all hydrazones possess greater proton affinity than the $E$ isomers. Hence, despite the fact that the stability of $E$ isomers is higher than that of the $Z$ forms, the cation formation ability of $Z$ isomers is higher than that of $E$ isomers. The obtained results suggest that the $Z$ isomer is more easily protonated than the $E$ isomer, which is more stable in neutral solutions. The obtained results suggest that quantum chemical calculations can be used to determinate the protonation sites and stability of the isomers.

Table 5

$E_{t o t}, \Delta H_{f}^{o}$ and $P A$ of the $Z$ and $E$ isomers calculated by the AM1 semiempirical method

\begin{tabular}{|c|c|c|c|c|c|c|}
\hline \multirow{2}{*}{\multicolumn{2}{|c|}{$\begin{array}{c}\text { AM1 } \\
\text { Compound } \\
\end{array}$}} & \multicolumn{2}{|c|}{ Neutral form } & \multicolumn{3}{|c|}{$s p^{2}$ protonated form } \\
\hline & & \multirow{2}{*}{$\frac{E_{\text {tot }}}{-73003.34}$} & \multirow{2}{*}{$\frac{\Delta H_{f}^{0}(\mathrm{~B})}{20.48}$} & \multirow{3}{*}{$\begin{array}{c}E_{\mathrm{tot}} \\
-73160.64 \\
-73163.94\end{array}$} & \multirow{2}{*}{$\frac{\Delta H_{f}^{\mathrm{o}}\left(\mathrm{BH}^{+}\right)}{178.09}$} & \multirow{2}{*}{$\frac{\text { PA }}{209.59}$} \\
\hline & $E$ & & & & & \\
\hline $\mathbf{H}_{1}$ & $Z$ & -73000.88 & 22.95 & & 174.79 & 215.36 \\
\hline \multirow[b]{2}{*}{$\mathbf{H}_{2}$} & $E$ & -76599.40 & 16.27 & -76754.10 & 171.51 & 211.96 \\
\hline & $Z$ & -76595.60 & 15.08 & -76758.8 & 166.81 & 215.47 \\
\hline \multirow[b]{2}{*}{$\mathbf{H}_{3}$} & $E$ & -83980.70 & -13.84 & -84133.4 & 141.32 & 212.04 \\
\hline & $Z$ & -83975.50 & -15.64 & -84139.40 & 135.32 & 216.24 \\
\hline \multirow[b]{2}{*}{$\mathbf{H}_{4}$} & $E$ & -81307.60 & 13.57 & -81462.90 & 173.18 & 207.59 \\
\hline & $Z$ & -81304.90 & 16.30 & -81466.30 & 169.76 & 213.74 \\
\hline \multirow{2}{*}{$\mathbf{H}_{5}$} & E & -80397.30 & -24.31 & -80554.10 & 133.75 & 209.14 \\
\hline & $Z$ & -80394.80 & -21.85 & -80557.80 & 130.04 & 215.31 \\
\hline
\end{tabular}

Table 6

$E_{t o t}, \triangle H_{f}$ and $P A$ of $Z$ and $E$ isomers calculated by the PM3 semiempirical method

\begin{tabular}{|c|c|c|c|c|c|c|}
\hline \multirow{2}{*}{\multicolumn{2}{|c|}{$\begin{array}{c}\text { PM3 } \\
\text { Compound }\end{array}$}} & \multicolumn{2}{|c|}{ Neutral form } & \multicolumn{3}{|c|}{$s p^{2}$ protonated form } \\
\hline & & \multirow{2}{*}{$\begin{array}{c}E_{\mathrm{tot}} \\
-66934.94 \\
-66933.50\end{array}$} & \multirow{2}{*}{$\begin{array}{c}\Delta H_{f}^{\mathrm{o}}(\mathrm{B}) \\
14.26 \\
15.74\end{array}$} & \multirow{2}{*}{$\begin{array}{c}E_{\mathrm{tot}} \\
-67127.06 \\
-67129.30\end{array}$} & \multirow{2}{*}{$\begin{array}{c}\Delta H_{f}^{0}\left(\mathrm{BH}^{+}\right) \\
175.71 \\
173.47\end{array}$} & \multirow{2}{*}{$\begin{array}{c}\text { PA } \\
205.75 \\
209.47\end{array}$} \\
\hline $\mathbf{H}_{1}$ & $\begin{array}{l}E \\
Z\end{array}$ & & & & & \\
\hline $\mathbf{H}_{2}$ & $\begin{array}{l}E \\
Z\end{array}$ & $\begin{array}{l}-70387.40 \\
-70386.20\end{array}$ & $\begin{array}{l}4.96 \\
6.10\end{array}$ & $\begin{array}{l}-70579.20 \\
-70583.00\end{array}$ & $\begin{array}{l}166.73 \\
162.87\end{array}$ & $\begin{array}{l}205.43 \\
210.43\end{array}$ \\
\hline $\mathbf{H}_{3}$ & $\begin{array}{l}E \\
Z\end{array}$ & $\begin{array}{l}-77147.70 \\
-77147.10\end{array}$ & $\begin{array}{l}-23.34 \\
-22.74\end{array}$ & $\begin{array}{r}-77339.70 \\
-77344.6\end{array}$ & $\begin{array}{l}138.24 \\
133.39\end{array}$ & $\begin{array}{l}205.62 \\
211.07\end{array}$ \\
\hline $\mathbf{H}_{4}$ & $\begin{array}{l}E \\
Z\end{array}$ & $\begin{array}{l}-73885.30 \\
-73884.00\end{array}$ & $\begin{array}{l}8.03 \\
9.29\end{array}$ & $\begin{array}{r}-74075.90 \\
-74079.3\end{array}$ & $\begin{array}{l}170.96 \\
167.58\end{array}$ & $\begin{array}{l}204.27 \\
208.91\end{array}$ \\
\hline $\mathbf{H}_{5}$ & $\begin{array}{l}E \\
Z\end{array}$ & $\begin{array}{l}-73711.90 \\
-73711.20\end{array}$ & $\begin{array}{l}-30.64 \\
-29.90\end{array}$ & $\begin{array}{l}-73903.70 \\
-73908.10\end{array}$ & $\begin{array}{l}131.12 \\
126.77\end{array}$ & $\begin{array}{l}205.44 \\
210.53\end{array}$ \\
\hline
\end{tabular}

\subsection{Experimental $p K_{B H}^{+}$values}

As indicated earlier, $\mathrm{p} K_{\mathrm{BH}}{ }^{+}$values are important to understand reaction mechanisms which involve proton transfers. The variation of the absorbance value that occurred when the $\mathrm{pH}$ of the solution was increased made it possible to determine the values of $\mathrm{pK}_{\mathrm{BH}}{ }^{+}$. The calculations were performed according to the procedure mentioned in the experimental part of this work. The statistical data (standard deviation (SD), relative standard deviation (RSD) and coefficient of determination $\left(R^{2}\right)$ ) were calculated, as well. The $\mathrm{pH}$ range of protonation, ionization ratio $(\log I)$ and $\mathrm{pK}_{\mathrm{BH}}{ }^{+}$values calculated from the absorbance data at an ionic strength of $0.5 \mathrm{~mol} / \mathrm{dm}^{3}$ are given in Table 7, while those calculated from the data at an ionic strength of 0.25 and $0.5 \mathrm{~mol} / \mathrm{dm}^{3}$ are not shown.

The corresponding average $\mathrm{p} K_{\mathrm{BH}}{ }^{+}$values for all investigated hydrazones obtained with the spectrophotometric method and their confidence intervals at the 95\% confidence level are presented in Tables 8 and 9 . The presented values are the average of the measurements of three series of solutions; the number of data used for calculations is 10 . 
Table 7

$p H, \operatorname{logI}$ and $p K_{B H}{ }^{+}$values of hydrazones $\boldsymbol{H 1}-\mathbf{H 5}$ (experimental spectra), $\mu=0.5 \mathrm{~mol} / \mathrm{dm}^{3}$

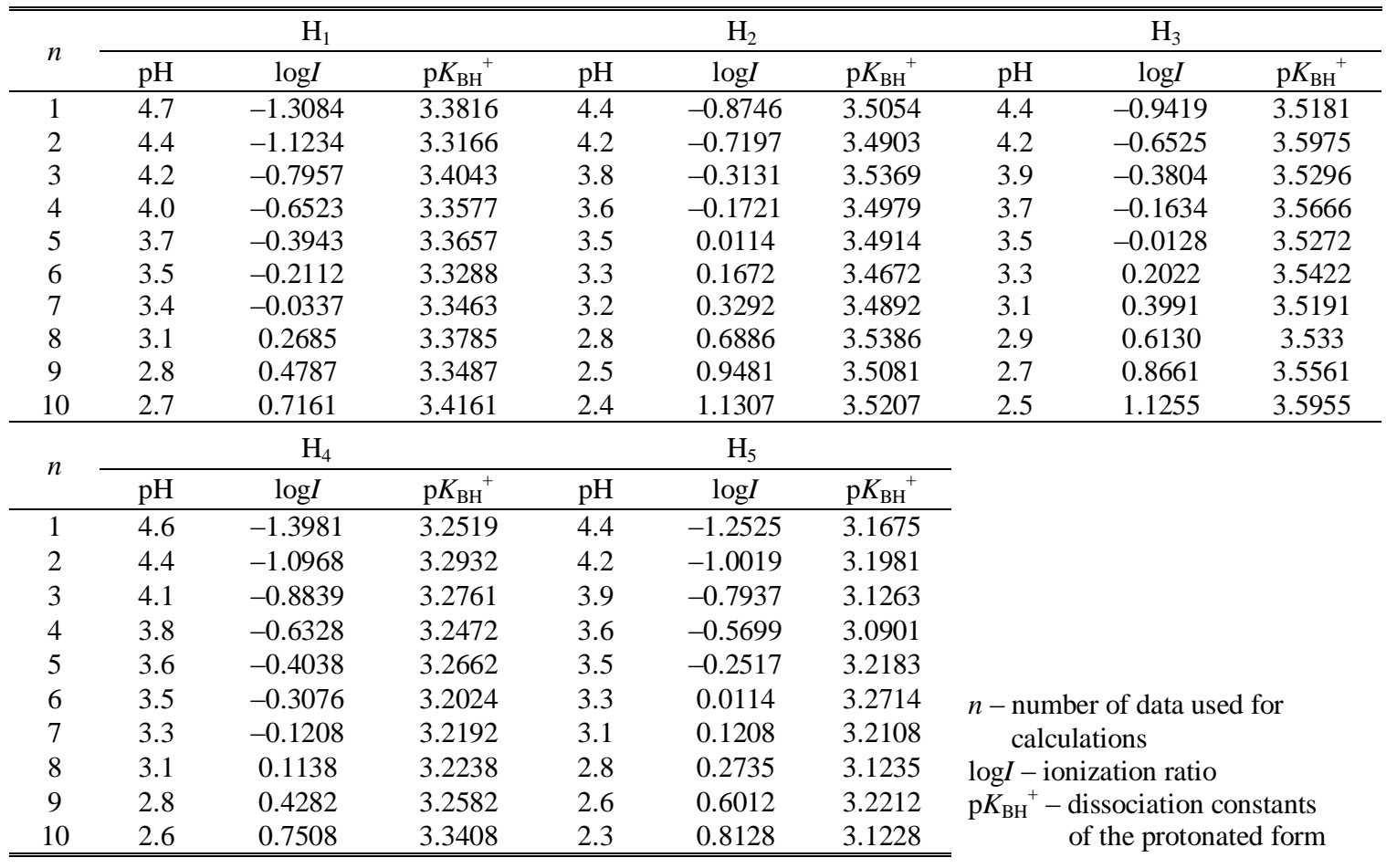

Table 8

$\mathrm{pK}_{\mathrm{BH}}{ }^{+}$values (numerically and graphically), thermodynamic $\mathrm{pK}_{B H}{ }^{+}$values and statistical data $\left(S D, R S D\right.$ and $R^{2}$ ) of hydrazones $\boldsymbol{H}_{1}-\boldsymbol{H}_{5}$ (experimental spectra)

\begin{tabular}{|c|c|c|c|c|c|c|c|c|}
\hline & $\mu\left[\mathrm{mol} / \mathrm{dm}^{3}\right]$ & $\varepsilon_{\mathrm{BH}}$ & $\varepsilon_{\mathrm{BH}}{ }^{+}$ & $\overline{1}{\mathrm{p} K_{\mathrm{BH}}{ }^{+}}^{+}$ & ${ }^{2} \mathrm{p} K_{\mathrm{BH}}{ }^{+}$ & ${ }^{1} \mathrm{SD}$ & ${ }^{1} \mathrm{RSD}$ & $\overline{1} R^{2}$ \\
\hline & 0.1 & 299768 & 27285 & $3.31 \pm 0.02^{*}$ & 3.32 & 0.03 & 0.91 & 0.999 \\
\hline \multirow[t]{3}{*}{$\mathbf{H}_{1}$} & 0.25 & 300371 & 27728 & $3.33 \pm 0.03$ & 3.35 & 0.04 & 1.36 & 0.997 \\
\hline & 0.5 & 300837 & 28079 & $3.36 \pm 0.01$ & 3.39 & 0.03 & 0.94 & 0.998 \\
\hline & \multicolumn{3}{|c|}{ Thermodynamic $\mathbf{p} K_{\mathrm{BH}}^{+}$} & 3.26 & 3.26 & & & \\
\hline \multirow{4}{*}{$\mathbf{H}_{2}$} & 0.1 & 302959 & 27772 & $3.43 \pm 0.03$ & 3.46 & 0.05 & 1.49 & 0.997 \\
\hline & 0.25 & 303523 & 28161 & $3.46 \pm 0.04$ & 3.49 & 0.06 & 1.72 & 0.996 \\
\hline & 0.5 & 303892 & 28431 & $3.50 \pm 0.01$ & 3.53 & 0.02 & 0.64 & 0.999 \\
\hline & \multicolumn{3}{|c|}{ Thermodynamic $\mathrm{p} K_{\mathrm{BH}}^{+}$} & 3.37 & 3.41 & & & \\
\hline \multirow{4}{*}{$\mathbf{H}_{3}$} & 0.1 & 369997 & 23088 & $3.50 \pm 0.04$ & 3.52 & 0.07 & 2.11 & 0.994 \\
\hline & 0.25 & 370304 & 23333 & $3.52 \pm 0.01$ & 3.54 & 0.01 & 0.42 & 0.999 \\
\hline & 0.5 & 369489 & 23389 & $3.55 \pm 0.02$ & 3.57 & 0.03 & 0.83 & 0.998 \\
\hline & \multicolumn{3}{|c|}{ Thermodynamic $\mathrm{p} K_{\mathrm{BH}}^{+}$} & 3.46 & 3.48 & & & \\
\hline \multirow{4}{*}{$\mathbf{H}_{4}$} & 0.1 & 223812 & 31037 & $3.23 \pm 0.02$ & 3.25 & 0.04 & 1.22 & 0.998 \\
\hline & 0.25 & 223870 & 31591 & $3.24 \pm 0.02$ & 3.26 & 0.03 & 0.96 & 0.998 \\
\hline & 0.5 & 224163 & 31163 & $3.26 \pm 0.02$ & 3.29 & 0.04 & 1.23 & 0.998 \\
\hline & \multicolumn{3}{|c|}{ Thermodynamic p $K_{\mathrm{BH}}{ }^{+}$} & 3.21 & 3.24 & & & \\
\hline \multirow{4}{*}{$\mathbf{H}_{5}$} & 0.1 & 423830 & 29887 & $3.13 \pm 0.03$ & 3.12 & 0.05 & 1.52 & 0.997 \\
\hline & 0.25 & 424423 & 30506 & $3.15 \pm 0.04$ & 3.14 & 0.07 & 2.22 & 0.995 \\
\hline & 0.5 & 424812 & 30950 & $3.17 \pm 0.03$ & 3.18 & 0.06 & 1.82 & 0.996 \\
\hline & \multicolumn{3}{|c|}{ Thermodynamic $\mathrm{p} K_{\mathrm{BH}}^{+}$} & 3.10 & 3.08 & & & \\
\hline
\end{tabular}

${ }^{1} \mathrm{p} \mathrm{KBH}^{+}$calculated from over determinated system of equations; ${ }^{2} \mathrm{p} K_{\mathrm{BH}}{ }^{+}-$graphically; ${ }^{1} \mathrm{SD}-$ standard deviation;

${ }^{1} \mathrm{RSD}$ - relative standard deviation; ${ }^{1} R^{2}-$ coefficient of determination; $\varepsilon$ - molar absorption coefficients $\left(\left[\mathrm{dm}^{3} \mathrm{~mol}^{-1} \mathrm{~cm}^{-1}\right]\right)$ of neutral $\left(\varepsilon_{\mathrm{BH}}\right)$ and protonated $\left(\varepsilon_{\mathrm{BH}}{ }^{+}\right)$form; ${ }^{*}$ confidence interval at the $95 \%$ confidence level 
Ta ble 9

$p K_{B H}{ }^{+}$values (numerically and graphically), thermodynamic $p K_{B H}{ }^{+}$values and statistical data $\left(S D, R S D\right.$ and $\left.R^{2}\right)$ of hydrazone $\boldsymbol{H}_{1}-\boldsymbol{H}_{5}$ (reconstructed spectra)

\begin{tabular}{|c|c|c|c|c|c|c|c|c|}
\hline & $\mu\left[\mathrm{mol} / \mathrm{dm}^{3}\right]$ & $\varepsilon_{\mathrm{BH}}$ & $\bar{\varepsilon}_{\mathrm{BH}}{ }^{+}$ & ${ }^{1} \mathrm{p} K_{\mathrm{BH}}{ }^{+}$ & ${ }^{2} \mathrm{p} K_{\mathrm{BH}}{ }^{+}$ & ${ }^{1} \mathrm{SD}$ & ${ }^{1} \mathrm{RSD}$ & ${ }^{1} R^{2}$ \\
\hline & 0.1 & 299783 & 30189 & $3.27 \pm 0.03^{*}$ & 3.24 & 0.05 & 1.59 & 0.997 \\
\hline \multirow[t]{3}{*}{$\mathbf{H}_{1}$} & 0.25 & 300195 & 30518 & $3.31 \pm 0.02$ & 3.27 & 0.04 & 1.32 & 0.997 \\
\hline & 0.5 & 300697 & 30721 & $3.36 \pm 0.04$ & 3.33 & 0.07 & 2.06 & 0994 \\
\hline & \multicolumn{3}{|c|}{ Thermodynamic $\mathrm{pK}_{\mathrm{BH}}^{+}$} & 3.20 & 3.16 & & & \\
\hline & 0.1 & 302268 & 27378 & $3.41 \pm 0.02$ & 3.42 & 0.03 & 0.95 & 0.998 \\
\hline \multirow[t]{3}{*}{$\mathbf{H}_{2}$} & 0.25 & 302917 & 27960 & $3.43 \pm 0.01$ & 3.45 & 0.02 & 0.85 & 0.999 \\
\hline & 0.5 & 303343 & 28262 & $3.46 \pm 0.02$ & 3.49 & 0.03 & 0.83 & 0.999 \\
\hline & \multicolumn{3}{|c|}{ Thermodynamic $\mathrm{pK}_{\mathrm{BH}}^{+}$} & 3.37 & 3.36 & & & \\
\hline \multirow{4}{*}{$\mathbf{H}_{3}$} & 0.1 & 370064 & 23091 & $3.50 \pm 0.03$ & 3.52 & 0.05 & 1.37 & 0.997 \\
\hline & 0.25 & 370488 & 23341 & $3.52 \pm 0.01$ & 3.53 & 0.02 & 0.68 & 0.999 \\
\hline & 0.5 & 370946 & 23826 & $3.54 \pm 0.02$ & 3.55 & 0.03 & 0.94 & 0.998 \\
\hline & \multicolumn{3}{|c|}{ Thermodynamic $\mathrm{pK}_{\mathrm{BH}}^{+}$} & 3.47 & 3.51 & & & \\
\hline \multirow{4}{*}{$\mathbf{H}_{4}$} & 0.1 & 222757 & 30358 & $3.22 \pm 0.03$ & 3.25 & 0.04 & 1.38 & 0.997 \\
\hline & 0.25 & 222611 & 31170 & $3.23 \pm 0.03$ & 3.26 & 0.04 & 1.34 & 0.997 \\
\hline & 0.5 & 222372 & 30438 & $3.24 \pm 0.04$ & 3.28 & 0.06 & 1.78 & 0.996 \\
\hline & \multicolumn{3}{|c|}{ Thermodynamic $\mathrm{pK}_{\mathrm{BH}}^{+}$} & 3.21 & 3.23 & & & \\
\hline \multirow{4}{*}{$\mathbf{H}_{5}$} & 0.1 & 426187 & 32306 & $3.12 \pm 0.02$ & 3.11 & 0.04 & 1.28 & 0.998 \\
\hline & 0.25 & 426707 & 32690 & $3.14 \pm 0.04$ & 3.13 & 0.07 & 2.32 & 0.994 \\
\hline & 0.5 & 427297 & 33149 & $3.17 \pm 0.04$ & 3.16 & 0.06 & 1.99 & 0.995 \\
\hline & \multicolumn{3}{|c|}{ Thermodynamic $\mathrm{pK}_{\mathrm{BH}}{ }^{+}$} & 3.08 & 3.07 & & & \\
\hline
\end{tabular}

${ }^{1} \mathrm{p} K_{\mathrm{BH}}{ }^{+}$calculated from over determinated system of equations; ${ }^{2} \mathrm{p} K_{\mathrm{BH}}{ }^{+}-$graphically; ${ }^{1} \mathrm{SD}-\mathrm{standard}$ deviation; ${ }^{1} \mathrm{RSD}-$ relative standard deviation; ${ }^{1} R^{2}-$ coefficient of determination; $\varepsilon$ - molar absorption coefficients $\left(\left[\mathrm{dm}^{3} \mathrm{~mol}^{-1} \mathrm{~cm}^{-1}\right]\right)$ of neutral $\left(\varepsilon_{\mathrm{BH}}\right)$ and protonated $\left(\varepsilon_{\mathrm{BH}}{ }^{+}\right)$form; ${ }^{*}$ confidence interval at the $95 \%$ confidence level

From the results presented in Tables 8 and 9 , it can be seen that the $\mathrm{p}{K_{\mathrm{BH}}}^{+}$values of all investigated hydrazones were quite similar. A small difference (lowest $\mathrm{p} K_{\mathrm{BH}}{ }^{+}$values) was noticed for hydrazone $\mathbf{H}_{5}$, which exhibited the strongest basic properties compared to the other investigated hydrazones. This may be expected by the influence of the hydroxyl group in its molecule.

The similarity between $\mathrm{pK}_{\mathrm{BH}}{ }^{+}$values was observed by comparison of the calculated $\mathrm{p}{\mathrm{BH}^{+}}^{+}$ values obtained from experimental data and from the reconstructed spectra. This result was expected because, as was already mentioned, in the experimental spectra, clear isosbestic points appear. This suggests that the $\mathrm{p} \mathrm{BH}^{+}$values were not significantly influenced by the solvent and the use of CVA in aqueous solutions is completely unnecessary.

The ionic strength of the solution also influenced the $\mathrm{p} K_{\mathrm{BH}}{ }^{+}$values. Hence, the obtained $\mathrm{p} \mathrm{K}_{\mathrm{BH}}{ }^{+}$ values at an ionic strength of $0.5 \mathrm{~mol} / \mathrm{dm}^{3}$ were greater than those calculated at the ionic strengths of 0.1 and $0.25 \mathrm{~mol} / \mathrm{dm}^{3}$.

The graphically obtained $\mathrm{p}{\mathrm{BH}^{+}}^{+}$values are presented in Tables 8 and 9. For illustration, the method of the graphical determination of the $\mathrm{p} \mathrm{BHH}^{+}$ value of the hydrazone $\mathbf{H}_{3}$ is shown in Figure 4.

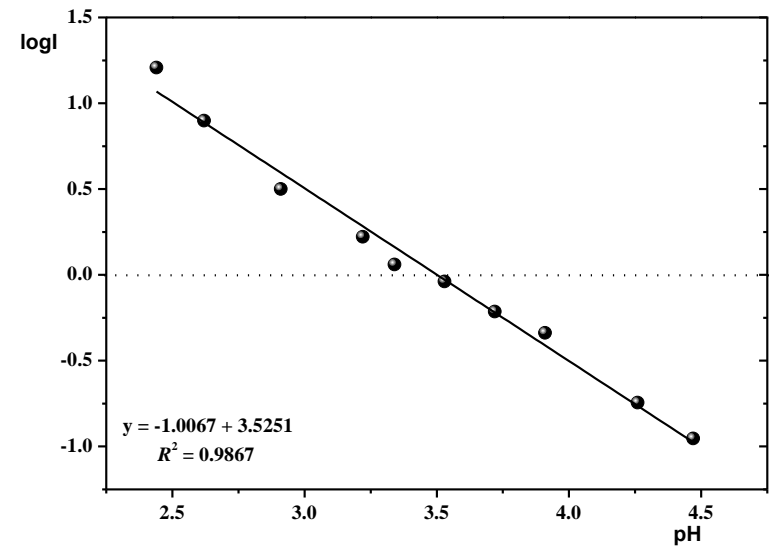

Fig. 4. Dependence of the ionization ratio $(\log I)$ for $N$-p-metoxybenzaldehyde- $p$-metoxybenzoilhydrazone $\left(c=3.21 \cdot 10^{-5} \mathrm{~mol} / \mathrm{dm}^{3}\right)$ on the $\mathrm{pH}$ of the solution, experimental spectra

As it can be seen in Figure 4, the correlation between $\log I$ and $\mathrm{pH}$ values is excellent with a regression coefficient $R^{2} \approx 1$. The slope of the correlation line is about unity. Also, there are no significant differences between the $\mathrm{p} \mathrm{B}_{\mathrm{BH}}{ }^{+}$values obtained numerically and graphically (see Tables 8 and 9 ).

As mentioned before, the thermodynamic $\mathrm{p} K_{\mathrm{BH}}{ }^{+}$values (Tables 8 and 9, indicated in bold) 
were evaluated at zero ionic strength. The dependence of $\mathrm{p} \mathrm{BH}_{\mathrm{BH}}^{+}$(at ionic strengths of $0.1,0.25$ and $0.5 \mathrm{~mol} / \mathrm{dm}^{3}$ ) on the $\sqrt{\mu}$ of the hydrazone $\mathbf{H}_{3}$ obtained from the experimental spectra are shown in Figure 5.

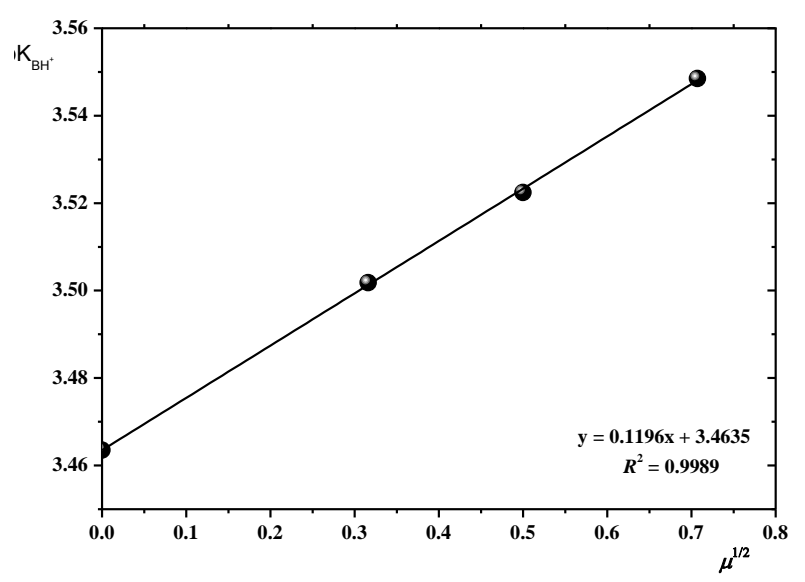

Fig. 5. Dependence of $\mathrm{p}_{\mathrm{BH}}{ }^{+}$values on $\sqrt{\mu}$ for $N$ - $p$-metoxybenzaldehyde- $p$-metoxybenzoilhydrazone, experimental spectra

The similarity between the thermodynamic $\mathrm{p} K_{\mathrm{BH}}{ }^{+}$values obtained from the experimental and reconstructed spectra is one more confirmation that the solvent has no important influence on the appearance of the spectra. The thermodynamic dissociation constants were also similar for all the investigated hydrazones and they were lower compared to the $\mathrm{p} \mathrm{K}_{\mathrm{BH}}{ }^{+}$values at the ionic strength of $0.1,0.25$ and $0.5 \mathrm{~mol} / \mathrm{dm}^{3}$. The calculated $\mathrm{p} K_{\mathrm{BH}}{ }^{+}$ values of the investigated hydrazones were similar to those obtained for a similar class of compounds $[31,32]$.

\section{CONCLUSION}

The acid-base properties of five $p$ substituted aromatic hydrazones were described using UV spectroscopy. The spectrophotometric data demonstrated that the reaction of protonation of the investigated hydrazones occurred in acidic media. The dissociation constant values of the protonated form were performed using the absorbance values selected at four wavelengths. The thermodynamic $\mathrm{p} K_{\mathrm{BH}}{ }^{+}$values were evaluated at zero ionic strength from the $\mathrm{p} K_{\mathrm{BH}}{ }^{+}$values determined at different ionic strengths. The calculated statistical data show that this method gives very precise values. The semiempirical methods AM1 and PM3 were employed in order to calculate some of the physicochemical parameters $\left(E_{\text {tot }}, E_{\text {bind }}, \Delta H_{\mathrm{f}}^{\circ}\right.$ and
$\left.\Delta G_{\mathrm{f}}\right)$ and proton affinities of both nitrogen ( $\mathrm{sp}^{2}$ and $\mathrm{sp}^{3}$ hybridized) protonated forms. The obtained results indicate that the imino $\left(\mathrm{sp}^{2}\right.$ hybridized) $\mathrm{ni}-$ trogen form is favored. Although the stability of the $E$ isomer is greater than that of the $Z$ isomer, the protonation of the $Z$ isomer is favored in acidic media. The results demonstrate that semiempirical calculations can be used successfully to determine the site of protonation, the stability of protonated forms and the stability of isomers.

\section{REFERENCES}

[1] S. Rollas, Ş. G. Küзükgüzel, Biological Activities of Hydrazone Derivatives, Molecules, 12, 1910-1939 (2007).

[2] M. Mohan, M. P. Gupta, L. Chandra, N. K. Jna, Synthesis, characterization and antitumor properties of some metal(II) complexes of 2-pyridinecarboxaldehyde 2'pyridilhydrazone and related compounds, Inorg. Chim. Acta, 151, 61-68 (1988).

[3] M. Al-Nuri, A. Haroun, I. Warad, R. M. Mahfouz, A. Al-Resayes, M. Ali-Shtayeh, Synthesis and characterization of some antifungal active hydrazones from combined of several functionalized hydrazides with di-2pyridil ketone, J. Saudi Chem. Soc., 11, 313-318 (2007).

[4] S. Sirdhar, M. Saravanan, A. Rauesh, Synthesis and antibacterial screening of hydrazones, Schiff and Mannich bases of isation derivatives, Eur. J. Med. Chem., 36, 615-625 (2001).

[5] B. Çakır, C. Dağ, E. Yıldırım, K. Erol, M. F. Şahin, Synthesis and anticonvulsant activity of some hydrazones of 2-[(3H)-oxobenzoxazolin-3-yl-aceto]hydrazide, J. Fac. Pharm. Gazi., 18, 99-106 (2001).

[6] U. Salgın-Gökşen, N. Gökhan-Kelekçi, Ö. Göktaş, Y. Köysal, E. Kılıç, Ş. Işık, G. Aktay, M. Özalp, 1Acylthiosemicarbazides, 1,2,4-triazole-5(4H)-thiones, 1,3,4-thiadiazoles and hydrazones containing 5-methyl2-benzoxazolinones: Synthesis, analgesic, antiinflammatory and antimicrobial activities, Bioorg. Med. Chem., 15, 5738-5751 (2007).

[7] M. Liu, Y. Wang, W. Wangyang, F. Liu, Y. Cui, Y. Duan, M. Wang, S. Liu, C. Rui, Design, Synthesis, and Insecticidal Activities of Phthalamides Containing a $\mathrm{Hy}-$ drazone Substructure, J. Agric. Food Chem. 58, 68586863 (2010)

[8] J. Pacansky, A. D. McLean, M. D. Miller, Theoretical Calculations and Experimental Studies on the Electronic Structures of Hydrazones and Hydrazone Radical Cations: Formaldehyde and Benzaldehyde Diphenylhydrazones, J. Phys. Chem., 94, 90-98 (1990).

[9] J. Mokhtari, M. R. Naimi-Jamal, H. Hamzehali, Quantitative Regeneration of Carbonyl Compounds from Oximes and Hydrazones by Gaseous Nitrogen Dioxide, 11th International Electronic Conference on Synthetic Organic Chemistry (ECSOC-11), 1-30 November, Santiago de Compostela, 11, a003 (2007).

[10] P. G. Chowdary, K. M. Reddy, V. K. Reddy, P. R. Reddy, 2-Hydroxy-1-naphthaldehyde-p-hydroxybenzoic 
hydrazone as a spectrophotometric reagent for the determination of lanthanium(III), Indian J Chem., 47A, 1381-1383 (2008).

[11] M. A. El-Taher, A. A. Gabr, Medium effect on acidity constants of some heterocyclic nitrogen azometines, $\mathrm{Ta}$ lanta, 43, 1511-1518 (1996).

[12] J. Ghasemi, S. Lotfei, M. Safaeian, A. Niazi, M. M. Ardakani, M. Noroozi, Spectrophotometric Determination of Acidity Constants of Alizarine Red S in Mixed Aqueous-Organic Solvents, J. Chem. Eng. Data, 51, 1530-1535 (2006).

[13] M. Singh, N. Raghav, Biological activities of hydrazones: A review, Int. J Pharm. Pharm. Sci., 3, 26-32 (2011).

[14] A. Albert, E. P. Serjeant, The Determination of Ionization Constants, Chapman and Hall Ltd.: London U. K., 1971.

[15] K. Kóczián, Z. Szakács, J. Kökösi, B. Noszaí, Sitespecific protonation microequilibria of penicillin and cephalosporin beta-lactam core molecules, Eur. $J$ Pharm. Sci., 32, 1-7 (2007).

[16] P. Przybylski, G. Bejcar, W. Schilf, B. Brzezinski, Structural and semiempirical investigation of hydrazone of gossypol and its protonated species, J. Mol. Struc. 878, 71-77 (2008).

[17] M. Jankulovska, K. Čolančeska-Rağenović, V. Dimova, I. Spirevska, P. Makreski, Synthesis and characterization of new $p$-substituted aromatic hydrazones, Org. Chem.:An Ind. J., 8, 326-334 (2012).

[18] M. Jankulovska, I. Spirevska, K. Č. Ragenoviќ, Behavior of some newly synthesized substituted 1,2,4triazoline-3-thiones in sulfuric acid media, Bull. Chem. Technol. Macedonia, 25, 29-37 (2006).

[19] G. Stojković, F. Anastasova, Protonation acidity constants for benzotoluidides in sulphuric acid solutions, Cent. Eur. J. Chem., 4, 56-67 (2006).

[20] D. Bonvin, D. W. T. Rippin, Target factor analysis for the identification of stoichiometric models, Chem. Engin. Sci., 45, 3417-3426 (1990).

[21] R. I. Zalewski, S. Géribaldi, Adaptation of characteristic vector analysis to $\mathrm{p} \mathrm{K}_{\mathrm{BH}}{ }^{+}$calculations of very weak bases from incomplete ultraviolet spectral data, J. Chem. Soc., Perkin Trans., 2, 113-115, (1988).

[22] B. Garcia, R. M. Casado, J. Castillo, S. Ibeas, I. Domingo, J. M. Leal, Acidity constants of benzamide and some ortho-substituted derivatives, J. Phys. Org. Chem., 6, 101-106 (1993).

[23] C. T. Davis, T. A. Geissman, Basic Dissociation Constants of Some Substituted Flavones, J. Am. Chem. Soc., 76, 3507-3511 (1954).

[24] E. J. King, Acid-Base Equilibria, Pergamon Press, Oxford, 1965.

[25] M. J. S. Dewar, E. G. Zoebisch, E. F. Healy, J. J. P. Stewart, Development and use of quantum mechanical molecular models. 76. AM1: A new general purpose quantum mechanical molecular model, J. Am. Chem. Soc., 107, 3902-3909 (1985).

[26] J. J. P. Steawart, Optimization of Parameters for SemiEmpirical Methods I-Method, J. Comput. Chem., 10, 209216 (1989).

[27] V. A. Kireev; Methods of Practical Calculations in Thermodynamics of Chemical Reactions, Khimiya, Moscow, 1975.

[28] M. J. S. Dewar, K. M. Dieter, Evaluation of AM1 Calculated Proton Affinities and Deprotonation Enthalpies, $J$. Am. Chem. Soc., 108, 8075-8086 (1986).

[29] B. I. Buzykin, A. P. Stolyarov, N. N. Bystrykh, The structure of the protonated forms of 1-hydrazinophthalazine and phthalazone hydrazone derivatives, Tetrahedron Lett., 21, 209-210 (1980).

[30] V. V. Zverev, T. N. Pylaeva, A. N. Stolyarov, P. Yu. Kitaev, A theoretical and experimental study of hydrazone protonation centres Russ. Chem. Bull., 26, 1175-1180 (1977).

[31] M. Jankulovska, I. Spirevska, V. Dimova, A UV study of the behavior of some benzaldehyde hydrazones in acid medium, J Iran. Chem. Soc., 8, 502-512 (2011).

[32] R. M. Issa, A. A. Hassanein, I. M. El-Mehasseb, R. I. A. El-Wadoud, UV-vis, IR and 1H NMR spectroscopic studies of some 6-chloro, 2-pyridyl hydrazones, Spectrochim. Acta A, 65, 206-214 (2006). 